\title{
Uprooting (Our) Whiteness
}

\author{
William R. Frey \\ Noelia Mann \\ Alex Boling \\ Parker Jordan \\ Karma N. Lowe \\ Susan S. Witte
}

\begin{abstract}
Social work education reinforces hegemonic Whiteness through pedagogies and practices that rely on an entitlement to and harvesting of Black, Indigenous, and People of Color's lived experiences for the purpose of its tacit audience: White students. Despite this exploitative and harmful reliance on objectified lived experiences, White students continue to lack critical understanding of their racial positionality and connections to racism. Uprooting Whiteness requires sitting with what it means for White people to be "a White problem." Drawing on the work of Yancy, we (group co-facilitators; our dean of diversity, equity, and inclusion; and three MSW student participants) describe the creation, organization, facilitation, and experiences of the first year of the Space for Uprooting Whiteness-a biweekly space where White social work students examine and uproot their relationship to White supremacy and domination. We argue for White social workers to take collective responsibility for racism in and beyond our institutions-requiring interrogation of our everyday practices and their (inter)dependence with and on systems of domination. This paper ends with three experiential narratives from student participants in the space and implications of critical intragroup dialogic pedagogy among White students in social work education and beyond.
\end{abstract}

Keywords: Whiteness, White supremacy, racism, anti-racism, social work education

Although social work holds social justice as a central ethical principle, social work education is steeped in White supremacist culture and ideologies (Ife, 2020; Tascon, 2020). Curricula and central texts have been written primarily by and for White people ${ }^{\mathrm{i}}$, lacking integration and representation of marginalized voices, narratives, and experiences. Centering the education of White students continues to harm Black, Indigenous, and People of Color (BIPOC) ${ }^{\mathrm{ii}}$ students through exploitation of their lived experiences with racism to educate White students (Srivastava, 1996) - or what Hartman (2020) named "a translation of Black suffering into white pedagogy." Of equal concern, White social work students graduate every year without critically understanding their role in (re)producing systems of Whiteness, racism, and how they cause harm through their everyday actions and behaviors as social workers and throughout their lives (Frey, 2018).

As social work programs begin to utilize the term "anti-racism" and shift curricula, we must recognize that these actions are insufficient for disrupting White people's investment in Whiteness and systems of racism. Interrogating and uprooting (our) Whiteness is a lifelong practice that extends beyond the classroom and social work into everything we

William R. Frey, MSW, doctoral student, Noelia Mann, MSW, Alex Boling, MSW, and Parker Jordan, MSW, alumni, Karma N. Lowe, Associate Dean of Diversity, Equity, and Inclusion, and Susan S. Witte, PhD, MSW, Professor, School of Social Work, Columbia University, New York, NY. 
believe and do. These practices have implications for our involvement in other people's lives and our (lack of) service to collective movements - that is to say, these practices are relational and shared. Despite the insufficiency of current symbolic institutional posturing - or perhaps because of it—we, as White students, faculty, staff, and administrators must develop an ongoing engagement-rooted in clarity and acknowledgement of our positionalities - with the reality of our educational environments and join the struggle against Whiteness.

In October 2019, 26 White-identifying students at Columbia School of Social Work (CSSW) began to meet in a Space for Uprooting Whiteness (SfUW), a biweekly intragroup dialogic space where White-identifying students examine and uproot their everyday relationship to Whiteness. This content and these processes are often missing from current social work pedagogy, despite their importance when engaging in professional uses of self. This paper is a descriptive and narrative exploration of the space's creation, facilitation, organizing principles, and expectations during the first year. It also includes narratives from three student participants who attended the space since its creation.

We begin with a brief history of White supremacy in social work education in the United States and frame our understanding of racialization and Whiteness. Then, we describe the events leading to the organization of the SfUW, including the original intentions, organizing principles, and expectations. Narratives written by three original participants highlight the various complex and conflicting experiences with this intragroup space. Finally, we discuss the implications of this dialogic pedagogy for White students in social work education and beyond. We end dedicated and unresolved.

\section{A Brief History of White Supremacy in Social Work Education}

From its inception in 1898, social work education in the United States has a long history of racism and White supremacy. Exemplifying the historical racism of the 20th century in the United States, many social work programs were racially segregated (Kayser, 2000), and evidence of integrated teaching or attention to needs other than those of White students is scant. Kayser (2000) noted that despite prominent Black social work educators addressing racial discrimination in the profession during the progressive era (Frazier, 1924), these voices were ignored. Instead, most texts and references on the history of social work education remained silent on the topic (e.g., Alexander, 1995; Austin, 1986; Hollis, 1951).

Indeed, a vanguard of Black social workers worked throughout the progressive era (Carlton-LaNey, 1999, 2001), including, Dr. E. Franklin Frazier, who established and accredited the Atlanta School of Social Work, the first Black school of social work, yet whose biography was not included in the Encyclopedia of Social Work until 1987 (Chandler, 2001). Frazier demonstrated an uncompromising stance against segregation, racism and oppression, believing that of the professions, social work had "the greatest promise for improving race relations," (Frazier, 1927, as cited in Bowles et al., 2016, p. 123). Frazier applied the "new psychology" of Freud to analyze race prejudice in Whites in "The Pathology of Race Prejudice." Published in 1927, the manuscript asked why White people, who were otherwise "kind and law abiding," were capable of "revolting forms of 
cruelty" towards Black people (Frazier, 1927, p. 857). Consequentially, he was dismissed from the Atlanta School and ended his association with social work, fleeing north from Atlanta under literal threat to his life (Chandler, 2001).

The 1960s and 1970s presented an opportunity for professional self-reflection on embedded racism that was clearly missed. In an aptly named essay, The Year 1968: The Turning Point When US Social Work Failed to Turn, Reisch (2018) reflected on how the profession was unprepared to respond to or join more radical social movements that were portents of change, many of which remain in this historic moment-such as calls to defund and abolish the police, rather than replacing police with social workers. At the height of the civil rights movement, leading social work publications made few references to racism or racial inequality (Simon, 1994, as cited in Reisch, 2018) and focused on individual interventions as opposed to advocacy and social justice.

In 1972, Longres described why social work education contributed to racism and why it was (and remains) difficult for social work education to commit itself to 'eradicating racism'. Social work education maintained racism through the exclusion of non-White students and faculty members from schools of social work, course content that emphasized subject areas and theoretical viewpoints that were "not particularly helpful to non-whites or those who are interested in working with the poor and non-white groups" (p. 35), and educational and socialization processes exclusive of non-Whites. Curricula remained largely White-centric, regardless of the growing and evident needs in non-White communities (Longres, 1972). Longres expressed the belief that "social work educators are collectively desirous of putting an end to racial strife in the United States by putting an end to racism. ... That is, we assume that social workers would want to change existing authority relationships so that more equitable arrangements come about" (p. 34). However, this historically familiar urgency and commitment - similar to calls in 2020 for increased attention to anti-racism in social work education-illustrates a pervasive, historical resistance to understanding the nature of White supremacy culture and its embeddedness in our pedagogy and professional practices, as opposed to individual racist acts and intentions.

Herrick (1978) articulated clarity about this resistance in social work and invited pedagogical innovations to address White supremacy in his thesis, which called out this paradox of the profession's ongoing attempts to address institutional racism through individual-level coursework and practice. Herrick acknowledged and argued that as long as the primary mission of social work education and practice is to help people live "within the existing institutions of our society," (p. 529) its mission serves to enhance-not dismantle - institutional racism, along with the other features of dominant institutions. Although attempts to incorporate materials related to 'ethnic and racial minorities' occurred in social work education, he maintained that institutional racism - as part of the fabric of the dominant institutions of society - would be further reinforced and perpetuated by adding this content to the social work curriculum (Herrick, 1978). These patterns of White supremacy and racism in social work pedagogy remained throughout the 20th century and we only begin to see movement toward addressing Whiteness in social work education in the 21 st century. 
"Teaching Notes" by Abrams and Gibson (2007) traced the evolution of multicultural education and teaching about diversity in social work, refocusing the profession's pedagogical attention to problematizing Whiteness. They acknowledged that teaching about diversity must include content on the workers themselves, including examining personal White privilege. Such content, borrowed from education and sociology, includes training teachers in concrete strategies and acknowledges that unlearning racism is a longterm process. Abrams and Gibson called on social work to "follow this trend," (p. 157) and echoed hooks (1994) in noting that "teaching and learning about cultural diversity often demands being comfortable with that which is uncomfortable" (p. 158). Even in this pivot to internal examination of White privilege, however, pedagogy remains centered on the needs of White social work students.

As Reisch (2019) examined issues of contemporary relevance through the lens of social work history, he found that the profession remains "torn between social justice and status enhancement ... between advocating for social reform and seeking elite support" (p. 581). White dominance can be seen through these reformist leanings and contradictory loyalties, which expose the profession of social work as a mode of White hegemonic social control. The need remains for pedagogical innovations to engage and disrupt Whiteness as a system of everyday domination in and beyond the classroom and profession.

\section{Whiteness}

The current pedagogies and practices of social work education reinstitute hegemonic Whiteness, training White social work students to secure White supremacy and domination through specific, everyday practices and procedures. For example, the normalized social work procedures we often unquestionably follow are rooted in specific racialized ideologies-like mandatory reporting, practices of client surveillance, and gatekeeping resources - and framed as innocuous and neutral. The continual reinstitution of hegemonic Whiteness requires "a process of domination or acts, decisions, and policies that white subjects perpetuate on people of color" (Leonardo, 2004, p. 137). Thus, any attempts at exposing and disrupting Whiteness necessitate an inquiry into "direct processes that secure domination and the privileges associated with it" (Leonardo, 2004, p. 137) - a focus on the everyday. As Yancy (2015) stated, "Much more is required at the level of white everyday practices and the ways in which those white practices re-center white power or challenge white power" (p. xii).

Everyday racist practices by White people are critical to securing hegemonic Whiteness - such as implicit devaluing and erasure of Black and Indigenous knowledge and people in social work classrooms by White educators. Essed (2008) described everyday racism as cumulative practices, often covert and hard to pinpoint, and drew connections between structural racism and these everyday practices: "There is no structural racism without everyday racism. ... By the same token, everyday racism is always structurally contextualized" (p. 214). The everyday actions of White social workers are of consequence. They carry the weight of sociopolitical histories of domination and power-beyond mere bias and prejudice, and beyond individual interactions. More specifically, Whiteness operates in and beyond individual actions, requiring White people to take account for how Whiteness operates through them, while acknowledging and situating those actions in the 
larger institutional and structural contexts of hegemonic Whiteness and systemic racism. Although this may be (mis)perceived as centering Whiteness, it is a acknowledgement and objectification of Whiteness not for hegemonic reinvestment, but for analyzing, challenging, and disrupting Whiteness as a constructed system of power with implications for social work education (e.g., Morrison, 1992; Roediger, 1998). Opportunities to interrogate systems of Whiteness are scant in diversity, equity, and inclusion courses, often reaching no further than racial identity development.

This call to take responsibility beyond our immediate actions runs contrary to the individuality embedded in Whiteness, rendering it a potentially powerful site for interrogation, disruption, and commitment to collective movements and action. For decades, BIPOC have been calling for White people to take action and commit to resistance movements and justice - especially with other White people in our own communities.

\section{"Get Your People"}

In his 1965 autobiography, Malcolm X asks the question: "How can white society atone for enslaving, for raping, for unmanning, for otherwise brutalizing millions of human beings, for centuries?" (X \& Haley, 1965, p. 377). He answers:

Combat, actively and directly, the racism in other white people. ... Where the really sincere white people have got to do their "proving" of themselves is not among the black victims, but out on the battle lines of where America's racism really is - and that's in their own home communities. (pp. 383-384)

Many Black people echo Malcolm X's sentiments, demanding that White individuals get your people (e.g., brown, 2020; Giorgis, 2016; Morris, 2016; Mystal, 2020; Oluo, 2017). In social work, White people have yet to significantly answer these calls to engage in antiracist practices with and take responsibility for other White people. These calls are often answered with White confusion and what seems to be the national White liberal anthem: "But what should or can I do?" This question is based on a limited framing of 'action' and 'doing', as if we are not engaging in actions and making decisions every day. Although that question is rarely generative, it does open space for White people to engage in groups, spaces, and practices to figure out better questions to ask of ourselves and other White people: What are our everyday practices and actions in and beyond social work? How do they affect BIPOC? How do they (re)secure and extend systems of Whiteness and racism? When we focus on our everyday actions and behaviors, how does our understanding of individual and collective action begin to shift?

\section{Conceptual Framings of Dr. George Yancy}

Yancy provided a critical framework for interrogating the everyday processes and practices of Whiteness and White racism. In this section, we introduce some of Yancy's concepts - ambush, arrival, crises, lingering, losing one's way, and (un)suturingcentering and taking seriously his question: How does it feel to be a White problem? 
In the introduction to White Self-Criticality beyond Anti-Racism, Yancy (2015) outlined various conceptual framings involved in processes of vigilance and interrogation around problematizing Whiteness and White people's relations to and investments in it. Yancy described Whiteness as "a master of disguise" (Yancy, 2015, p. xiii) with a shapeshifting capacity that can trick White people through attempts of self-mastery and the belief that we 'have things figured out'-aiming to master anti-racism so we can be absolved of our responsibility for and involvement in White racism (Yancy, 2015, 2016). However, he cautioned, Whiteness exists beyond the White self. If we see ourselves as anti-racist and make outward claims as such, we will inevitably face moments of ambush. Yancy (2015) described ambush as "a surprise attack, a form of attack that points to how whiteness insidiously returns, how it ensnares, and how it is an iterative process that indicates the reality of white racist relational processes that exceed the white self" (p. xiii). Arrival assumes we can create ourselves beyond Whiteness and White racism-systems that operate and implicate our actions beyond our autonomous control. This is insufficient for undoing Whiteness: "Whiteness is undone through profound irruptions that belie selfmastery" (Yancy, 2015, p. xiii). Forms of arrival can happen iteratively and necessitate processes of individual and shared interrogation and vigilance for unsettling the settled.

The process of White people claiming - and fighting - to be outside of and autonomous from Whiteness is an example of what Yancy (2015) calls suturing. He defined it as "the process whereby whites install forms of closure, forms of protection from counter-white axiological and embodied iterations, epistemic fissure, and white normative disruption" (p. xv). White people are socialized to engage in suturing, to protect not only the White self (which we mistakenly believe to be our natural and neutral self), but also systems of Whiteness and racism. Being unsutured, however, involves cultivating a dispositional and aspirational practice of "coming to terms with the realization that [our] embodied existence and embodied identities are always already inextricably linked to a larger white racist social integument or skin which envelops who and what [we] are" (Yancy, 2015, p. xvii). Being unsutured necessitates an engagement in processes of losing one's way. Yancy (2015) noted that "one must be prepared to linger, to remain, with the truth about one's white self and the truth about how whiteness has structured and continues to structure forms of relationality that are oppressive to people of color" (p. xv).

Given the impossibility of individually arriving beyond Whiteness as people categorized as White (at least at this moment and possibly our entire lives), Yancy emphasized the importance of cultivating spaces where students can experience crises (Yancy, 2015; Yancy \& del Guadalupe Davidson, 2014). In this context, he spoke of crises as decisions and of creating spaces where students can experience and practice deciding"a life of commitment to 'undo,' to 'trouble,' over and over again, the complex psychic and socio-ontological ways in which one is embedded in whiteness" (Yancy, 2015, p. xiv). The iterative and ongoing nature of this deciding is critical because "a single action or intention does not 'undo' whiteness" (p. xiv).

The SfUW is an initial attempt at cultivating a space for 'putting Whiteness in crises' among White social work graduate students through the modality of critical intragroup dialogue (Yancy \& del Guadalupe Davidson, 2014). Traditionally, intergroup dialogues seek to provide a structured space for meaningful engagement between two or more social 
identity groups, potentially with a history of conflict (Ford \& Orlandella, 2015; Zúñiga et al., 2007). Critical dialogue seeks to engage power and privilege and how they structure life for specific groups of people, while cultivating individual and collective responsibility for engaging in social justice work (Delgado \& Stefancic, 2000; Freire, 1970; Nagda \& Maxwell, 2011). These framings inform our understandings and practices of critical intragroup dialogue.

We create experiences of being in crises through prompts, activities, naming and questioning dynamics, and delaying or resisting arrival at solutions or answers in hopes of building White graduate students' capacities to take these practices into their everyday and intimate lives. As painful as it is for students to be in what they termed "existential crises," Yancy argued this is critically necessary for continued involvement in shared practices of disrupting Whiteness - disrupting false beliefs of arrival from Whiteness. The SfUW attempts to disturb forms of arrival and learned practices of suturing through experiences of crises, losing our (individual and collective) way, and unsuturing. However, cultivating a space for holding and engaging in such practices is a constant challenge, because it may easily (re)produce Whiteness and White racism without iteratively questioning itself. Critical intragroup dialogue may allow for this type of iterative and constant questioning.

\section{The Space for Uprooting Whiteness}

The SfUW began as a biweekly space where White graduate students confront what it means to be (categorized as) White. This confrontation includes coming to terms with having specific (individually unique and collectively interrelated) relationships to systems of racism and grappling with what it means to uproot and divest from those relationships as individuals and a collective. Based on the principles of critical intragroup dialogue, we attempt to co-create a space to engage our relationships to Whiteness in and among people who are positioned as White. Although this may seem counterintuitive-White people engaging in dialogues about racism and Whiteness by ourselves - research has shown that White people can effectively learn about and foster responsibility regarding race, racism, and Whiteness through structured intragroup dialogic spaces and affinity groups (Ford, 2012; Ford \& Orlandella, 2015; Tatum, 2017).

Despite the potential educational efficacy of intragroup dialogic groups, many remain skeptical of these white spaces (Delgado, 2017; Hughey, 2007) - and rightfully so. Research has shown that "antiracist work among whites even with the knowledge of institutional racism and in viewing the world in color-conscious ways, still allows forand perhaps even facilitates - the reproduction of racism" (Hughey, 2007, p. 96). Hughey (2007) mentioned common problems among White anti-racists, like essentializing race and making Whiteness everything. Although our article does not tackle all these challengesand we may often find ourselves involved in their perpetuation - we felt it is important to mention them here. These sites of unease with intragroup spaces are ongoing points of reflection and contention in the SfUW.

It is necessary to note that social work education attempts to engage in intergroup dialogic practices in classrooms across the United States (e.g., White and BIPOC students). Although much research supports the effectiveness of these practices in fostering learning 
and cultivating relationships among students from different social positionalities (Dessel \& Rodenborg, 2017; Nagda et al., 2009; Zúñiga et al., 2007), these attempts may still lead to further harm to BIPOC students as White students engage in suturing strategies to separate themselves from responsibility and harm - centering their emotions and selves.

The SfUW diverges from more traditional intragroup dialogic spaces, which often have a narrow identity focus on how participants socially and personally identify themselves (often stripped of political implication). We structure our conversations around White positionality. In her 1988 paper arguing for a new feminist theory of gendered identity, Alcoff presented the concept of positionality - one that may be useful for understanding the White racialized subject. Positionality refers to

...a posit or construct, formalizable in a nonarbitrary way through a matrix of habits, practices, and discourses ... an interpellation of our history within a particular discursive constellation, a history in which we are both subjects of and subjected to social construction (Alcoff, 1988, p. 431).

As individuals and a collective, we attempt to locate our habits, practices, discourses, and selves in systems of Whiteness and racism, critically engage with how these systems position us in relation to other people, and what anti-racist actions this positioning may require of us in various everyday contexts.

Many students who participate in the SfUW have a specific, and limited, understanding of Whiteness. Often, they have rarely uttered the word. Many are beginning to engage with what it means to be White and have White privilege. However, when participants first enter the space, these are still individual pursuits: becoming 'better White people' and 'less harmful'. Work such as this would fall into the category of White reconstruction, or seeking to "transform whiteness, and therefore white people, into something other than an oppressive identity and ideology" (Leonardo, 2009, p. 92). Fewer students enter the space with intentions and framing of the other main camp of Whiteness intervention, White abolition, which positions Whiteness as irredeemable - "not merely oppressive and false, it is nothing but oppressive and false" (Roediger, 1994, p. 13). Although many participants engage in practices of White reconstruction, we seek to complicate and interrogate these actions. The SfUW seeks to employ Leonardo's (2009) comparative conclusion: "There is a way that reconstructionism would provide the entrance into whiteness and abolitionism its exit" (p. 105). The following section describes the timeline of the SfUW's creation, the original organizing principles, and expectations of the space.

\section{Brief History of the Space}

For many years, CSSW has wrestled with a climate and culture where BIPOC students have felt and are marginalized in the classroom, often by White peers. Through some recognition of Whiteness and how they perpetuate White supremacy, some White peers have sought to find ways to dismantle this specter of Whiteness. In 2013, a student leader attempted to create a "white anti-racist group," motivated by the desire to not put any emotional labor on BIPOC classmates in discussions about White privilege. After three meetings, the group disbanded, and its creation was not embraced by BIPOC students. An 
attempt was made again in 2016, with some White-identified students attempting to form a student group called "Unpacking Identities of Privilege." Unfortunately, organizing meetings led to lack of consensus in the group, and it never officially coalesced. In 2018, in conjunction with the creation of an Office of Diversity and Inclusion and the integration of a required course with a lens on power, race, oppression, and privilege, the need for a 'White accountability space' became amplified. In August 2018, William Frey-a doctoral student - met with a CSSW professor (Susan Witte), a student from a prior White affinity space (Alex Boling), and the assistant dean for diversity, equity, and inclusion (Karma Lowe) to consider how to create a consistent and intentionally facilitated space (all coauthors of this paper). In late October 2018, the first SfUW gathering was held with 26 student participants -25 master's students and 1 doctoral student.

\section{Organizing Principles}

The space is organized based on three main purposes. First, the SfUW attempts to provide a space for White people to interrogate (their own) Whiteness without acting on their presumed entitlement to and harvesting of BIPOC students' lived experiences. Much of social work pedagogy situates BIPOC as the only people who have racialized experiences. There is often an unspoken expectation in the classroom that BIPOC students must engage in the mental, emotional, and intellectual labor of rehashing their knowledge and experiences for the benefit of White students and their learning (Srivastava, 1996). The space challenges White students to question their own relations to Whiteness and systemic racism.

Second, the space intends to support White students in the lifelong process of building everyday practices of considering and confronting their racial positionality and role in sociopolitical systems of White racism. Students often frame anti-racist actions as additional things they must do, rather than acknowledging our everyday actions that reify racism and investments in White hegemony. Actions like protests, further education and awareness raising, and calling other people out for their racism are often the focus of White conversations about action. Although these actions can have critical impacts, what happens when we interrogate the mundane moments of our everyday life: the procedures we follow at work and in institutions; the everyday decisions we make that seem unquestionable and common sense? Each moment is a site of recentering or challenging Whiteness.

Part of confronting the truth about our racial positionalities is recognizing the limitations of our individual actions for challenging and disrupting systems of racism (i.e., What can individual actions do and not do?) and understanding which disruptions require our involvement in collective actions and movements. Although it is necessary to explore how we must shift our individual actions and behaviors, these shifts are often insufficient for addressing systems of White hegemony and racism. If participants have intentions of self-mastery and individual White reformation, they are likely to engage in work rooted in the mistaken belief that they can be autonomously White and harmless - separate from Whiteness. This requires telling ourselves the truth by asking ourselves: What are we (not) doing? What is the space (not) doing? 
The third purpose of the space is to challenge students to engage in these (anti-racist) practices in their everyday and intimate lives, where hegemonic Whiteness normatively exists and functions without thought or challenge. The spaces where we protect and invest in Whiteness are often the spaces where we rarely consider its involvement and influence. We attempt to create a space where participants question how their intimate lives are informed by and built on systems of Whiteness. We also ask: What must change in our intimate lives? What must be questioned and changed in our families, friendships, intimate partnerships, and workspaces? Again, Whiteness roots itself in the places we do not want to look.

\section{Expectations}

To follow through on these organizing principles, the SfUW has three expectations for participation, which are shared with all prospective participants: consistently showing up, meeting with accountability partners, and engaging in critical reflective processing. The first expectation is consistent attendance and participation in the biweekly facilitated spaces. Consistency is critical for building capacity and embodying processes of uprooting Whiteness. Harkening to the work of Herrick in 1978, simply adding content to social work programs to address the need for anti-racist practices cannot disrupt the embeddedness of White supremacy in the academy. Systems of hegemonic Whiteness-including social work education - continue to socialize people every day. Our practices of resisting this socialization must also be daily and active if we are ever going to shift our worldview and actions.

The second expectation is that participants meet with their accountability partners between spaces. An accountability partner is another participant in the group who can provide a space for support and challenge outside of the facilitated space. Toward the end of each session, each participant is paired with another participant (this person rotates every week to build networks of challenge and support). They are expected to meet for at least 30 minutes between spaces. Some weeks, there may be specific prompts and activities for this time. For example, participants were asked to build a vision for the future and then, with their accountability partner, interrogate the silences and gaps in their vision (e.g., How do White ideologies and racism play a role in this envisioned future?). Other weeks, it is up to the participants to use the time to process their personal experiences related to race, racism, and Whiteness.

The participants are reminded that these accountability partnerships are foundationally rooted in challenging and pushing each other deeper into the process and practice- these partnerships are not intended to coddle, although this is something to continually notice. They are a resource for continuing conversations and experiences that happen in the space. Because White people often rely on the educational labor of BIPOC for White education and discovery, we must build racial stamina for seeing, questioning, and engaging Whiteness and racism with other White people (DiAngelo, 2018).

The final expectation is that participants engage in some form of individual reflective processing. Processing can be an important tool for building a consistent critical reflective practice of understanding race, racism, Whiteness, and our own positionality as individuals 
in relation to one another, institutions, and systems. Between each space, participants are asked to intentionally reflect on their experiences in and beyond the SfUW. This expectation is important for participants to build personal accountability and prioritize this work of confronting their racial positionality in their inevitably busy lives. If the participants find themselves not engaging in this practice or becoming comfortable and complacent with their practices, it is up to them to consider why and make adjustments, while utilizing the space and their accountability partners.

\section{BIPOC Participants/Observers in the SfUW}

The original invitation for the SfUW mentioned that although the space is intended for White-identifying or -identified participants, no one would be turned away. ${ }^{\text {iii }}$ BIPOC students have attended the space in different capacities - some as observers, others as participants. When a BIPOC student expresses interest in attending the space, we are honest about the racial positionalities of the facilitators (both White) and the vast majority of the participants (also White), including the potential limitations of the space to deliver what they may be seeking, despite everyone having a relation to Whiteness. We also give interested BIPOC students examples of how BIPOC have been involved in the past. They then define their own role and the terms of their involvement. Most people who have observed the space identify as Black and most who decided to participate identify as nonBlack or multiracial/mixed. For example, after moving from in-person to online dialogues, one person visited the space with their camera and microphone off for a few weeks. Others have and continue to participate weekly, engaging with their relationship to Whiteness as BIPOC. It is important to mention that BIPOC participation in the SfUW is not meant to be an accountability mechanism, nor is anything expected in return (e.g., feedback). As people learn about the space, many express interest in observing, and we find it necessary to make that available for BIPOC students.

\section{Participant Reflections on the SfUW}

From the SfUW's inception, it has been the facilitators' intention for participants to be co-creators and have agency in shifting, changing, and reimagining the space. In the spirit of this co-creation, the following vignettes are reflections by social work student participants involved in the space from the start in response to the prompts: What brought you to the space? What keeps you coming back? How have you changed over the last year?

To prepare this manuscript, each participant shared multiple drafts and the facilitators asked further questions, mirroring how we engage in the space. However, these reflections did not necessarily need to promote the space or speak of it kindly. Each vignette shows some of the various and often differing experiences of participants, and we hope they bring to life the theoretical and conceptual work outlined thus far - especially the messiness and ongoing challenges. The vignettes are the original words of the participants and have not been modified. 


\section{“Confronting My (White) Body" (Noelia Mann)}

My first draft of this piece was a series of about 50 questions I have come to ask myself over the course of my participation in the Space for Uprooting Whiteness. I thought these might be an accurate reflection of my process thus far, and where I'm at today. More importantly, I wanted to write something I could look back on in 10 years and not feel embarrassed about. Something others could read, especially the People of Color in my life, and still possibly think of me as "good." Because the thing about just asking questions is you don't have to tell anyone what you think.

Thankfully, participating in the SfUW has meant there are people to check my bullshit. William has said often that the nature of Whiteness is that it's sneaky, it changes. It will look different in the future, and so I should respond to it differently. I should hate this in a few years (or days ...) if it's going to be of any value at all, and it should mean confronting my fear of being "found out" as racist, problematic, "bad," etc. I am all of those things and I need to stop pretending I can trick people into not finding out. As my partner once said to me: "They already know you're White."

I wrote that list of 50 questions because I thought I was protecting myself, but I was actually protecting Whiteness. It's a mistake I've been making for a long time, because I've bought into the lie, articulated poignantly by James Baldwin, that Whiteness is who I am, rather than what I am/have been categorized as (Pavlić, 2014). When Whiteness is who I am, attacks on Whiteness become existential, making it almost impossible not to respond with defensiveness. And it means I'm making the same decision my ancestors made, at various points in history, when they decided to buy into the invention of Whiteness in order to advance their own interests.

I'm not suggesting distancing from or denying my Whiteness, and I'm not suggesting that I don't go through the world deeply benefitting from the many ways Whiteness is designed to ensure and protect my comfort, safety, enjoyment, wealth, status, health, and so on. Those things are deeply true, and I learn more about them every day. But, by agreeing that White is who I am, it means that I'm putting my energy and attention towards finding 'healthy', less-harmful ways to be White (one of the reasons I articulated for joining the group on my first day). In doing so, I am still investing in, rather than putting my energy towards destroying, the system and structures of Whiteness.

When I do turn my attention and energy in that direction, I find myself, inevitably, inescapably, confronted with the reality of my body. Race and racism manifest their harm upon bodies (Coates, 2015), and so it makes sense that any exploration of racialization has to include (I'd argue, center) the body. The thing is, I've spent most of my life not engaging with my body, doing anything I can to escape it, to escape the present moment. Unable to sit with what is, I've sought to destroy it. Unsurprisingly, much of my (conscious and unconscious) visualization of antiracist work has been about destroying my body as wellas if somehow by peeling off my white skin, by annihilating my white body, I could, in some small way, annihilate racism too.

I've come to understand the many ways in which this is untrue, including (1) the false power this gives me, as one (White) individual, to impact racism and White supremacy; 
and (2) the fact that Whiteness is far more than skin deep (Bennett, 2020). It lives deep inside me (Bellamy, 2020), in my spinal cord, my muscles, my conscious and unconscious memory. It manifests itself in the many ways I physically and emotionally experience false senses of ease, constriction, and fragility, which then forces me to confront the terrifying possibility that my most basic "instincts," the "authentic" truths I believe my body to hold, are shaped by and in service of White supremacy. To confront the possibility that I don't know myself at all (Yancy, 2015).

Challenging ease is painful. A little voice in the back of my head/heart says, "can't there just be one thing that's easy, that feels good?" But if something requires the domination and exploitation of others, is it actually easy? Does it actually feel good? Is it possible that what I think feels good actually doesn't? The kind of ease I feel around other White people, for example, is based on the belief that they don't represent an existential threat to my self-narrative as a "good White person." The physical ease manifests in very real behavior; I am a better listener, I am more able to receive people as complex and multifaceted, I practice fewer reassurance-seeking behaviors that demand emotional labor. How does this "misidentified ease" then uphold, protect, and serve White supremacy? What is being required of me in order to experience that ease? More broadly, what does the White body have to do in order to be settled in a world of White supremacy? (Menakem, 2017).

On the other end of the experiential spectrum lies constriction; the way my body physically contracts during moments of perceived racial threat (i.e., when my "good White person" narrative is challenged). That contraction transforms into the dominating and manipulating behaviors of White fragility (DiAngelo, 2018) as I frantically seek an end to the unbearable constriction (not, notably, an end to Whiteness). What purpose is this constriction serving? How does it support the compartmentalization Whiteness thrives upon? How might finding expansiveness in those moments, instead, allow me to behave differently?

In My Grandmother's Hands, Resmaa Menakem (2017) locates these experiences of ease and constriction alongside what he calls "false fragility," or the belief that "we white people are incapable of soothing ourselves and feeling safe in the presence of Black bodies. We are not just physically vulnerable; we are also emotionally helpless when we are around Black bodies" (p. 104). I think this is especially true in the construction of White womanhood, which is cast as doubly vulnerable. How does the belief that I'm feeble and helpless - physically, but also, and importantly, emotionally - in the presence of Black bodies serve Whiteness? How is it reinforced by the myriad formalized institutions aimed at soothing my constriction, especially as a White woman? How can I understand social work as one of those institutions? Moreover, how does my White "fretting" (as another student in the group put it), the vocal anxiety about being "good" that so seems to plague the construction of White womanhood in particular, actually protect whiteness by saying "Here, look how badly I want to get it right, you'll break me if you tell me I fucked up."

The ultimate question is, literally, "Who do you think you are?" and, just beyond the question, the possibility of not knowing. I guess I could wrap my head around the idea that my thoughts and behaviors are shaped by White supremacy, as long as my body, my unconscious - what I identify as my "authentic" self - are untouched. As long as they are 
still "good." What if, in addition to not literally being possible, the whole construction of "good White person" is an intentional distraction, designed to keep me pouring my energy into making sure I am, or am perceived as, "good," and turning my antiracism into what Zoé Samudzi calls "a quest for white redemption" (Instagram Highlight, July 29, 2020)? It keeps (and is meant to keep) me focused on chasing ease, minimizing constriction, believing in my own false fragility, and behaving, for all intents and purposes, like Black lives don't matter, regardless of what I say.

\section{“Shifting Without Resolution" (Alex Boling)}

This drafting process has provoked deep feelings of anxiety, fear, and shame as I am tempted to present a perfectly packaged and performative story of my transition from a harmful White person to a "good" antiracist. The truth is I feel chaotic in my thoughts, hesitant in my actions and inactions, and I'm still grappling with my role and responsibilities in this work daily.

Initially I desired a space outside of classrooms and away from the inevitable exploitative labor of BIPOC colleagues to learn how to not cause harm as a social worker. After witnessing attempts at a space for White social workers at CSSW who wanted to support antiracism, I was unsettled by the focus on external group actions without discussion of internal processes. While I didn't have the words for my feelings at the time, my inherent belief in the dignity of all human beings was compelling me to become more aware of my own biases and problematic thinking. While I believe in the value of protests, donations, and contacting legislators, none of those address my individual conditionings, habits, beliefs, and the ways I move through the world.

I thought that I would arrive at understanding racism and at being antiracist. I thought that if I could identify where Whiteness resides in me, then maybe I can figure out how to extract it, or at least distance myself from it. If I can do that, I can achieve "antiracism" and be absolved of the ways my Whiteness benefits me at the violent expense of my BIPOC clients, friends, and colleagues. This long-held belief dismisses that racism is systemic, constructive, and adaptive. I cannot undo it as an individual.

I have come to understand my individual work as the continuous learning and challenging of beliefs and choices I make each and every day-how I challenge the status quo. How do I embrace the risks and consequences of daily practices to examine and challenge my Whiteness and position in society, knowing that even in this process I make choices that consciously and subconsciously perpetuate racism individually and systemically?

Building a consistent individual practice of interrogating everything that comes to my mind has often felt overwhelming and cyclical. I've come to realize my so-called "spin cycles" do not serve this work well, but they're important for me to understand and acknowledge. One of my internal thoughts has looked like the following:

My mental health is deteriorating and preventing me from engaging deeper in these thoughts. Personal suffering must not be anti-racist. Racism is dehumanizing. Personal wellness must then be an anti-racist practice. But 
centering my personal needs can't be anti-racist because I'm White and centering myself. Does this mean personal wellness is only challenging racism when it's done by BIPOC? Can I attend to my personal needs without attending to my Whiteness? Hating myself is not serving anyone. Am I allowed to have compassion and gentleness for myself, if I need it to sustain this work? But what does that say about meeting White folks where they are? Does this not just continue to center Whiteness? How much of this thinking is rooted in tenets of White dominance?

I am aware that I can't stay here. If systemic racism is ever going to end, then White folks and those who benefit from Whiteness can't stay here. Systems and those who defend them cannot stay here. Here meaning unchanged, unmoved, unwilling to devote time, energy, risks, and resources to change, while BIPOC continue to experience violence and death. Whiteness is aggressively self-preserving though. Most of the time, I will be here in spite of any individual efforts. I feel urgency in my limitations in moving differently, with myself, with my relationships, within larger societal structures. This ongoing interrogation also highlights my individual limitations in this work. I have internalized limitations as weakness, and by hyper-focusing on myself, I'm actively resisting thinking about myself as part of a racial collective. I am engaged in this work because change needs to happen, individually and collectively.

I remember my body would begin slipping into a fight-or-flight response when responding to the simplest "Why are you here?" questioning almost a year ago. A year later, that stress response has lessened as the interrogation has become normalized. My stamina to hold conversations has expanded, and because I'm not as constantly in fight-orflight mode, I actually have physical and emotional space to critically examine my relationship with Whiteness. At the same time, I am recognizing a hypervigilance around my self-interrogation that sometimes feeds into my general anxiety. This has led me to consider different supports for my mental health. My questions are also changing. As soon as I become a little comfortable and fully knowing that I'm always going to be part of what is referred to as a "white problem" (Yancy, 2015), a new situation, or thought, or challenge, inevitably pulls any shred of certainty from under me.

The longer I spend in the space, the more able I am to critique the limitations of the space itself. We lack direct accountability from BIPOC, and the nature of the space encourages closer community with other White folks, which takes up energy and resources, which have all been topics of conversation in the group without resolution. At the same time, I have needed this provocation. I have needed relationships with others who could call me out or in, who could relate to my "spin cycles," and who could challenge everything I bring and push me to dig deeper. This group was willing to offer the accountability structure I sought and cannot get from other communities in my life. It has enabled me to continue to name other tools and resources and communities I need in order to continue the work outside of the space. At the beginning of last year, my social work community was my only community having this conversation. I have a baseline set of expectations that I now try to bring to other spaces in my life to assess if/how they will allow me to do the work there too. 
I'm also still exploring how to accept my whole self and love my whole self, if part of my identity is always tied to Whiteness. Awareness that I have limited control over how I will harm BIPOC always invokes a visceral reaction. How I choose to carry that without allowing it to paralyze me is one of my current explorations. It also requires me to acknowledge that I am a human being who will keep messing up. But I need to push myself to show up anyway. I think my inability to accept collective action right now comes from the need to protect myself. If everything I focus on is individual, it centers me, and I believe I can control that narrative. Joining and supporting collective work means not only believing other voices and experiences, but choosing to relinquish control to those voices.

But there is no "escape button" from Whiteness. I'm still struggling to figure out how to accept this, incorporate it into my emotional experience, relational experiences, and perceptions of myself and others. This always leads me to wonder, "What do I $D O$ with this? What is the point if I can't ever truly escape the larger structures and values of White dominance that sanction my existence in this world?" I'm finding that it helps me to recognize my paralysis as an indicator that I am spending too much time in my head and that I need to check in with my body. When I'm feeling self-loathing, it helps for me to question my self-worth narrative and where that narrative originated. What would it look like for me to shift the framing of myself as Whiteness, and instead look at myself as a beneficiary of Whiteness and conditioned by Whiteness? This shift leads me from accepting blame to accepting responsibility and an obligation to engage in the work. It compels me to move instead of remaining stagnant. This messy tension is a practice in what Yancy refers to as "unsuturing" or leaving myself open to the pain and stress of this work and resisting the urge to close myself off from vulnerability.

I frequently feel as though I should know/be/do more and differently. I know there isn't a place of arrival, but that doesn't stop me from subconsciously still trying to get there, and it surely doesn't suggest that there isn't progress to be made and work to be done.

\section{"What Brought Me in (and out of) the Space" (Parker Jordan)}

As news about the group's creation spread through CSSW, I was fixated on finding out who had signed off on it. I knew that the previous attempt at holding a White affinity group had caused significant discomfort, and in some cases outright harm, among Black classmates and other classmates of color. I wanted to know from whom the group had approval, or to whom the group was accountable. (A conflation, I realize now, of two different things.) I wasn't sure how the space could exist in a way that did not do more harm than good. Despite my reservations, I wanted to be in the loop on whatever larger conversations were happening within CSSW related to students' own Whiteness.

At the time, I didn't see myself as being very connected to the larger White CSSW community. I felt I had a different relationship both to Whiteness and to social work than many of my White classmates did, almost like my Whiteness was on one side of a scale, against which my queerness, my transness, my mental illness, my lower-income background, etc. were combined and weighed. I viewed my Whiteness as a compartmentalized bad thing that I needed (with much guilt and shame) to quickly and quietly minimize so as not to be a problem for the People of Color in my life. 
My desire to confirm that there had been some sort of trusted administrative sign-off on the space was a form of my own approval seeking, in itself demonstrating how terrified I was of being implicated in the White supremacy that manifested itself daily within CSSW. This fear led me to avoid association with anyone I perceived as one of the harmful White people there, and I clung to even the smallest indications from People of Color that I was conducting myself acceptably. I misunderstood accountability to be an act, and in this context, one taken by a White person or people at CSSW to obtain permission from an unspecified Black person or people at CSSW to hold the space. While this was an incredibly messed up and dehumanizing framing, I was too preoccupied with staying distanced from other people's Whiteness to examine what my own was producing.

The first night in the space, Will referenced our tendency to locate White supremacy as being outside of ourselves. I realized in that moment that I secretly considered myself, especially in the context of CSSW, one of the "good" White people. Embarrassed that as a trans person I was still buying heavily into a different false binary, I decided to keep participating to work through why. I wanted to process what it meant that I tried so hard to separate myself from other White people in my profession, and what it could look like to do otherwise. I saw value in cultivating a practice of engaging more with other White people about our Whiteness, especially with other White social workers, regardless of whether we knew each other well or I perceived us to be in similar headspaces.

In the year since then, I've experienced a huge shift from considering uprooting Whiteness to be hard and challenging, but necessary work, to seeing it more as something I'm excited and eager to do in order to be in better community with the people around me. I'm no longer so invested in trying to distance myself from Whiteness by elevating other identities that I somehow feel tip the scales and align me more with "oppressed" than "oppressor." I've also stopped compartmentalizing my Whiteness, viewing myself not as "white but also trans, queer, etc." but rather White and my other identities, and White in my other identities. I'm eager to examine how White supremacy is deeply entrenched, upheld, and perpetrated throughout all my identities, relationships, and interactions.

With different needs and priorities than when I first joined the space, I ultimately decided to stop attending. I left the space because we weren't holding each other accountable to uproot Whiteness in our social work practice specifically, and because I realized the space wasn't where I wanted to prioritize having conversations about other aspects of my life. Participants in the space rarely talked about our shared profession at all - to the extent that someone who joined later in the semester told me it took her several weeks to realize we were all social workers. My admittedly late attempt to consciously shift the space in this direction did not produce much sustained conversation either. It speaks volumes that a room of White people co-created a space to discuss White supremacy as mostly located away from our shared profession, rather than one where we supported each other in examining and taking accountability for how we perpetuate White supremacy in our work.

As we weren't talking about social work, I began to really question why I was investing so deeply in conversations within the space when most participants were not people with whom I was otherwise in community. Talking with people who didn't know me outside 
the context of the space limited the specificity and applicability of our conversations. Uprooting Whiteness felt increasingly difficult in a space where many of the identities and relationships most central to my life weren't present, shared, or seen in a way that lent itself well to my taking active accountability. I can't imagine I was alone in feeling this. Holding a space where our Whiteness is inherently decontextualized (because our day-to-day lives are the context, we're mostly strangers, and we're not talking about social work) in my opinion makes this sort of tension unavoidable.

As I continue to reflect on my time participating in the space, I've realized that for a time it gave me an elusive sense of "doing the work," but in a way that lessened my sense of urgency for having these discussions with people who know me well. I also remain uncomfortable with the intimacy and solidarity I began to feel with other participants in the space prior to leaving. I believe that cultivating a sense of closeness and community based solely on shared Whiteness is irresponsible and harmful, and at the same time can't imagine how I could have held people I met with for several hours every week at arm's length.

\section{Discussion}

These illustrative vignettes offer unique perspectives on how the various concepts of Yancy - ambush, (lack of) arrival, crises, lingering, losing one's way, and (un)suturing show up in the reflective work of students as they seek to address his question: "How does it feel to be a White problem?" Students displayed a reflective practice of locating themselves in relation to Whiteness, which is rarely cultivated in social work educational spaces. They displayed the usefulness of not centering Whiteness through hegemonic normalization, but objectifying and analyzing it through confronting its role throughout our lives (including in social work as trained social workers).

Noelia Mann lingers with connections of Whiteness to the body, demonstrating a practice of disturbing her own potential moments of tempting but fictional arrival beyond Whiteness. She engages in a messy and ongoing confrontation of her inevitable relationship to Whiteness. When Whiteness is understood as what we are, rather than who we are, our vantage point shifts, and we are able to - as Mann suggests - shift our attention away from investments in a so-called personal 'healthy Whiteness' towards our role in collective struggles against systems of Whiteness. Alex Boling provides us with a vulnerable look into the internal pressures to perform a "good" and "harmless" Whiteness and arriving at "self-mastery." Similar to Mann's explanation of annihilating the White body, Boling expresses a desire to "extract" Whiteness from herself. These lines of reflection represent the challenging confrontation of the constructed/imagined overlaps between Whiteness, our bodies, and our humanity. Throughout her reflections, Boling presents the psychological toll it takes when attempting to disentangle how Whiteness has attached to our lives, ideologies, meaning-making, and life practices, while building the stamina to continually show up - even though she acknowledges an ongoing resistance to engage beyond the individual work.

Parker Jordan's vignette poses important challenges to the SfUW, directly naming a continued resistance to confront Whiteness in social work and the messiness of building 
community in an intragroup dialogic setting founded on a collective relationship to Whiteness. While ultimately deciding to stop attending, Jordan highlights a recognition of the shifts in his understandings of Whiteness and clarity around prioritizing this work in other areas of his life. Still, we sit with Jordan's poignant acknowledgement that the SfUW may give us a false sense of 'doing the work', releasing any urgency for engaging in other forms of collective action (e.g., mobilization and organization).

All three students provide insight into their everchanging understanding of what it means to be in proximity to Whiteness, and all that it entails. The uniqueness of each vignette highlights the different priorities of each student, who may require different educational support (even if this leads them to leave the group). As these priorities change and students sharpen their reflective and analytic understanding, it is inevitable that the space must be questioned - as well as become questionable - and in some cases, abandoned. Our investments do not lie in the group, but in students continuing to show up and engage in individual and collective work throughout the various spaces of their lives. Nevertheless, few White social work students and educators consistently practice confrontation and engagement of our proximities to Whiteness. If we are unable to build everyday practices of divesting from and organizing against Whiteness, there is little hope we can disrupt its further reproduction in social work and beyond.

\section{Conclusions and Implications}

We argue for White social workers to take collective responsibility for racism in and beyond institutions - requiring interrogation of our everyday practices and their (inter)dependence with and on systems of White domination. Two main intentions of the SfUW are to complicate students' understandings of Whiteness and begin to see our everyday and intimate lives as sites for the (re)production and challenge of hegemonic Whiteness. Regardless of the impacts, questions remain about the space, social work education, and the role of people categorized as White in collective movements against Whiteness and racism. What role do spaces such as the SfUW play in the journey and struggle against hegemonic Whiteness? What is the space doing to and for participants throughout their lives? Is the SfUW similar to or different than other spaces, and if so, in what ways? Should effectiveness of the space be measured, and if so, using what metrics? What unique challenges and opportunities does social work pose for processes of uprooting Whiteness?

In 1920, W.E.B. Du Bois (1999) wrote: "The discovery of personal whiteness among the world's people is a very modern thing - a nineteenth and twentieth century matter, indeed" (p. 17). Until the 21 st century, social work education —or perhaps more broadly, our entire U.S. educational enterprise-has mostly resisted any attention to Whiteness. Currently, social work education (often through diversity, equity, and inclusion) situates Whiteness as something a person has, often as an identity, with little focus on Whiteness as processes and practices securing domination. This leads many White students to come to abstract conclusions - such as "I am White" and "I have White privilege"-with little engagement in what these declarations mean (Frey, 2018). As schools of social work proclaim commitments to try anything and everything to further anti-racist pedagogy, what 
are the implications of further institutionalizing such spaces and practices? How can the work of uprooting Whiteness happen in racialized institutions, and can this be carried out at all by the institution itself? (see, Ray, 2019). Finally, how can and should we connect shared practices in spaces such as these to larger, collective movements led by BIPOC organizers? How is this already being done, and what role does social work education play in furthering these connections?

The SfUW cannot and will never be sufficient by itself for disrupting and abolishing Whiteness. Nor is it meant for that. It is nothing more or less than an ever-changing process for cultivating and sustaining capacity for White people's involvement in individual and collective shared practices for disrupting hegemonic Whiteness and systems of racismthe capacity to act at any given moment, whatever that moment requires (not necessarily attachment to any specific actions). The sole act of meeting in the SfUW and with other White people does nothing to disrupt Whiteness. Disruption is based in practice and cannot be found in intention. It comes down to what is done in the space and how this connects White people to broader struggles against Whiteness and systemic racism (e.g., current abolitionist organizing through direct action, protest, sabotage, and community building against capitalism, colonialism, and imperialism).

In 1874, Brooklyn schoolteacher, William J. Wilson-signing himself as Ethiopasked the question, "What for the best good of all shall we do with the White people?" (Roediger, 1998, p. 66). Leonardo (2009) expansively echoed: "What are we to do with whiteness?" It is clear that education without collective action-where social work education and pedagogy sits right now-is not enough to address systemic inequity (Ray \& Aja, 2020). We hope these words - in conversation with Yancy, Leonardo, and many others - can lead to deeper commitments of losing our way, while engaging in shared practices to abolish and divest from everyday practices of hegemonic Whiteness in and beyond social work education.

\footnotetext{
i Though contentious, we chose to capitalize "White" and "Whiteness" throughout this article for the sake of clarity and consistency. However, it is important to note that this term involves many layers of sociopolitical, legal, and historical construction - categorization, classification, identification, ideology, culture, and imagination (see, for example, Ewing, 2020; Painter, 2020).

ii We use the term "BIPOC" throughout this article unless context requires more specificity, also involving the abovementioned layers of construction. We made this decision to acknowledge the unique ways that Whiteness affects varying groups of people (e.g., systems of anti-Black racism and settler colonialism), while recognizing that any generalizing term is insufficient to truly do so.

iii Additionally, the space has had White participants from outside social work, including the mother of a former CSSW student. This presented added facilitation and practice challenges. The COVID-19 pandemic pushed the space online, and the global Black Lives Matter protests expanded the number and pool of group participants beyond CSSW and the profession of social work in summer 2020. This required us to expand our content and context beyond social work to meet the needs of new participants.
} 


\section{References}

Abrams, L. S., \& Gibson, P. (2007). Teaching notes: Reframing multicultural education: Teaching white privilege in the social work curriculum. Journal of Social Work Education, 43(1), 147-160. https://doi.org/10.5175/jswe.2007.200500529

Alcoff, L. (1988). Cultural feminism versus post-structuralism: The identity crisis in feminist theory. Signs: Journal of Women in Culture and Society, 13(3), 405-436. https://doi.org/10.1086/494426

Alexander, C. A. (1995). Distinctive dates in social welfare history. In R. L. Edwards (Ed.), Encyclopedia of social work (Vol. 3, pp. 2631-2647). NASW Press.

Austin, D. M. (1986). A history of social work education (Vol. 1). University of Texas at Austin, School of Social Work.

Bellamy, S. (2020, June 8). Performing whiteness. The Paris Review. https://www.theparisreview.org/blog/2020/06/08/the-performance-of-white-bodies/

Bennett, B. (2020). The vanishing half. Riverhead Books.

Bowles, D. D., Hopps, J. G., \& Clayton, O. (2016). The impact and influence of HBCUs on the social work profession. Journal of Social Work Education, 52(1), 118-132. https://doi.org/10.1080/10437797.2016.1112650

brown, a. m. (2020, June). a word for white people, in two parts [Blog]. Wordpress. http://adriennemareebrown.net/2020/06/28/a-word-for-white-people-in-two-parts/

Carlton-LaNey, I. (1999). African American social work pioneers' response to need. Social Work, 44(4), 311-321. https://doi.org/10.1093/sw/44.4.311

Carlton-LaNey, I. (Ed.). (2001). African American leadership in social work history: An empowerment tradition. NASW Press.

Chandler, S. K. (2001). E. Franklin Frazier and social work: Unity and conflict. In I. Carlton-Laney (Ed.), African American leadership: An empowerment tradition in social welfare history (pp. 189-201). NASW Press.

Coates, T. (2015). Between the world and me. Spiegel \& Grau.

Delgado, D. (2017). Whites only: SURJ and the Caucasian invasion of racial justice spaces. https://medium.com/the-establishment/whites-only-the-caucasian-invasion-ofracial-justice-spaces-7e2529ec8314

Delgado, R., \& Stefancic, J. (Eds.). (2000). Critical race theory: The cutting edge. Temple University Press.

Dessel, A. B., \& Rodenborg, N. (2017). An evaluation of intergroup dialogue pedagogy: Addressing segregation and developing cultural competency. Journal of Social Work Education, 53(2), 222-239. https://doi.org/10.1080/10437797.2016.1246269

DiAngelo, R. (2018). White fragility: Why it's so hard for white people to talk about racism. Beacon Press. 
Du Bois, W. E. B. (1920). Darkwater: Voices from Within the Veil. Harcourt, Brace and Howe.

Essed, P. (2008). Everyday racism. In D. T. Goldberg \& J. Solomos (Eds.), A companion to racial and ethnic studies (pp. 202-216). Blackwell. https://doi.org/10.1111/b.9780631206163.2002.00020.x

Ewing, E. L. (2020, July). I'm a Black scholar who studies race. Here's why I capitalize 'White.' https://zora.medium.com/im-a-black-scholar-who-studies-race-here-s-why-icapitalize-white-f94883aa2dd3

Ford, K. A. (2012). Shifting White ideological scripts: The educational benefits of inter-and intraracial curricular dialogues on the experiences of White college students. Journal of Diversity in Higher Education, 5(3), 138-158. https://doi.org/10.1037/a0028917

Ford, K. A., \& Orlandella, J. (2015). The "not-so-final remark" the journey to becoming White allies. Sociology of Race and Ethnicity, 1(2), 287-301. https://doi.org/10.1177/2332649214559286

Frazier, E. F. (1924). Education of colored social workers in the South. NATCS Bulletin. Rockefeller Foundation Archives, Folder 6.

Frazier, E. F. (1927, June). The pathology of race prejudice. The Forum, 77(6), 856-862.

Freire, P. (1970). Pedagogy of the oppressed (M. B. Ramos, Trans.). Continuum.

Frey, W. R. (2018, December). Letter to the editor: Confronting whiteness. Columbia Spectator. https://www.columbiaspectator.com/opinion/2018/12/03/letter-to-the-editorconfronting-whiteness/

Giorgis, H. (2016, November). How white people can support people of color now. Buzzfeed News. https://www.buzzfeednews.com/article/hannahgiorgis/how-whitepeople-can-support-people-of-color-right-now\#.cg130EVd1

Hartman, S. (2020, July 4). Saidiya Hartman on insurgent histories and the abolitionist imaginary (Catherine Damman, Interviewer) [digital interview transcript]. https://www.artforum.com/interviews/saidiya-hartman-83579

Herrick, J. E. (1978). The perpetuation of institutional racism through ethnic and racial minority content in the curriculum of schools of social work. Journal of Sociology \& Social Welfare, 5(4), 527-537. https://scholarworks.wmich.edu/cgi/viewcontent.cgi? article=1299\&context=jssw

Hollis, E. V. (1951). Social work education in the United States: The report of a study made for the National Council on Social Work Education. Columbia University Press.

hooks, b. (1994). Teaching to transgress: Education as the practice of freedom. Routledge.

Hughey, M. W. (2007). Racism with antiracists: Color-conscious racism and the unintentional persistence of inequality. Social Thought \& Research, 28, 67-108. https://doi.org/10.17161/str.1808.5218 
Ife, J. (2020). Whiteness from within. In S. M. Tascón \& J. Ife (Eds.), Disrupting Whiteness in social work (pp. 26-42). Routledge. https://doi.org/10.4324/9780429284182-3

Kayser, J. (2000). The early history of racially segregated, Southern schools of social work requesting or receiving funds from the Rockefeller philanthropies and the responses of social work educators to racial discrimination. Rockefeller Archive Center. https://www.issuelab.org/resources/27812/27812.pdf?download=true

Leonardo, Z. (2004). The color of supremacy: Beyond the discourse of 'white privilege.' Educational Philosophy and Theory, 36(2), 137-152. https://doi.org/10.1111/j.14695812.2004.00057.x

Leonardo, Z. (2009). Race, whiteness, and education. Routledge.

Longres, J. (1972). The impact of racism on social work education. Journal of Education for Social Work, 8(1), 31-41. https://doi.org/10.1080/00220612.1972.10671900

Menakem, R. (2017). My grandmother's hands: Racialized trauma and the pathway to mending our hearts and bodies. Central Recovery Press.

Morris, S. M. [crunkadelic]. (2016, November 9). Get your people. Crunk Feminist Collective. https://www.crunkfeministcollective.com/2016/11/09/get-your-people/

Morrison, T. (1992). Playing in the dark: Whiteness and the literary imagination. Cambridge, Mass: Harvard University Press.

Mystal, E. (2020, June 3). To the white people who keep asking how to 'help'. The Nation. https://www.thenation.com/article/society/white-people-anti-racism/

Nagda, B. A., Gurin, P., Sorensen, N., \& Zúñiga, X. (2009). Evaluating intergroup dialogue: Engaging diversity for personal and social responsibility. Diversity \& Democracy, 12(1), 4-6. https://www.aacu.org/publicationsresearch/periodicals/evaluating-intergroup-dialogue-engaging-diversity-personal-and

Nagda, B. A., \& Maxwell, K. E. (2011). Deepening the layers of understanding and connection: A critical-dialogic approach to facilitating intergroup dialogues. In K. E. Maxwell, B. A. Nagda, \& M. C. Thompson (Eds.), Facilitating intergroup dialogues: Bridging differences, catalyzing change (pp. 1-22). Stylus. https://doi.org/10.1353/csd.2012.0066

Oluo, I. (2017, October). Ijeoma Oluo: 'I am drowning in whiteness'. National Public Radio. https://www.kuow.org/stories/ijeoma-oluo-i-am-drowning-in-whiteness

Painter, N. I. (2020, July). Why 'White' should be capitalized, too. The Washington Post. https://www.washingtonpost.com/opinions/2020/07/22/why-white-should-becapitalized/

Pavlić, E. (2014, March 14). James Baldwin's white history month. Africa is a Country. https://africasacountry.com/2014/03/james-baldwins-whitehistoryweek-as-long-as-youthink-youre-white-youre-irrelevant 
Ray, V. (2019). A theory of racialized organizations. American Sociological Review, 84(1), 26-53. https://doi.org/10.1177/0003122418822335

Ray, V., \& Aja, A. (2020, June 18). Racism isn't about ignorance. Some highly educated people have upheld systemic inequality. The Washington Post. https://www.washingtonpost.com/nation/2020/06/18/racism-isnt-about-ignorancesome-smartest-minds-have-upheld-systemic-inequality/

Reisch, M. (2018). The year 1968: The turning point when US social work failed to turn. Critical and Radical Social Work, 6(1), 7-20. https://doi.org/10.1332/204986018x15199226335079

Reisch, M. (2019). Lessons from social work's history for a tumultuous era. Social Service Review, 93(4), 581-607. https://doi.org/10.1086/706741

Roediger, D. R. (1994). Towards the abolition of whiteness: Essays on race, politics, and working class history. Verso.

Roediger, D. R. (1998). Black on white: Black writers on what it means to be white. Schocken Books.

Srivastava, S. (1996). Song and dance?: The performance of antiracist workshops. Canadian Review of Sociology, 33(3), 291-315. https://doi.org/10.1111/j.1755618x.1996.tb02454.x

Tascon, S. (2020). Disrupting white epistemologies: De-binarising social work. In S. M. Tascón \& J. Ife (Eds.), Disrupting Whiteness in social work (pp. 8-25). Routledge. https://doi.org/10.4324/9780429284182-2

Tatum, B. D. (2017). Why are all the Black kids sitting together in the cafeteria? And other conversations about race. Basic Books.

X, M., \& Haley, A. (1965). The autobiography of Malcolm X. Grove Press.

Yancy, G. (2015). Introduction: Un-sutured. In G. Yancy (Ed.), White self-criticality beyond antiracism (pp. xi-xxvii). Lexington Books.

Yancy, G. (2016). Black bodies, white gazes: The continuing significance of race in America. Rowman \& Littlefield.

Yancy, G., \& del Guadalupe Davidson, M. (Eds.). (2014). Exploring race in predominantly White classrooms: Scholars of color reflect. Routledge. https://doi.org/10.4324/9780203416716

Zúñiga, X., Nagda, B., Chesler, M., \& Cytron, A. (2007). Intergroup dialogue in higher education: Meaningful learning about social justice. ASHE Higher Education Report, 32(4), 1-128. https://doi.org/10.1002/aehe.3204

Author note: Address correspondence to William R. Frey, School of Social Work, Columbia University, New York, NY, 10027. Email: wf2220@,columbia.edu 